MedieKultur | Journal of media and communication research | ISSN 1901-9726

Article

\title{
Realism as a third film practice
}

\section{Birger Langkjær}

MedieKultur 2011, 51, 40-54

Published by SMID | Society of Media researchers In Denmark | www.smid.dk The online version of this text can be found open access at www.mediekultur.dk

The concept of realism may owe much of its success to its vague definition. This article suggests that it can be useful as a term that covers a central, mainstream film practice in European and other national cinemas, located somewhere in between genre films and art films. The concept refers to a serious kind of film that does not obey classical genre rules, but nevertheless tells its stories in an accessible and often engaging form that, generally speaking, creates a more popular (yet serious) film than the art film. As a film practice, it cuts across well known but often vaguely defined sub-categories, such as social realism and psychological realism. Finally, it is argued that the dichotomy between Hollywood genre films and European art cinema ignores both national variants of basic genres and a tradition of realism as a mainstream film practice.

\section{Introduction}

The main objective of this article is to substantiate the view that the common conceptual dichotomy within film studies between Hollywood genre films and European art cinema ignores, among other things, a major tradition of filmmaking in European cinema that broadly can be characterised as a tradition of realism. This realism does not simply consist of single "realistic" features within otherwise very different kinds of films. In fact, the term realism may prove to be useful for covering a mainstream film practice in European cinema 
(and probably in other national cinemas) that lies somewhere in between what film studies usually refer to as genre films and art films. It is a serious kind of film (as opposed to a comedy) that does not obey classical genre rules, but nevertheless tells its stories in an accessible and often engaging form that, generally speaking, makes it a more popular film than the art film. As a film practice, it encompasses well known but often vaguely defined sub-categories, such as social realism and psychological realism.

\section{Genre films and other kinds of films}

The concept of genre is used in very different ways. In literature it is often defined in relation to different forms of enunciation (epic, drama, lyric), whereas in film studies it is most often (but not always) defined in relation to subject matter: "[In literature] genre divisions have been made on the basis of formal distinctions (the novel, drama, poetry) compared with the subject or content divisions more usual in film criticism" (Ryal, in Neale, 2000, p. 19).

Within broader media studies, genre can be used to refer to specific subcategories within fiction (e.g., crime fiction), but it can also refer to a form of communication that includes all kinds of enunciation, styles, subject matters and subcategories of fictions, such as is the case with commercials for television. In other words, it is not only that there is no single criterion by which a genre can be defined: genres are not even defined on the same level. Basically, genre is about textual norms that guide media production, the form and content of specific media products and viewer expectations. Further, specific genres often facilitate specific kinds of experiences. In this sense, any aesthetic artefact can be described in terms of genre and specific genre-related norms.

In film studies, however, the reference point for discussions of film genre is usually the Hollywood tradition: "The definition and discussion of genre and genres in the cinema has tended to focus on mainstream, commercial films in general and Hollywood films in particular" (Neale, 2000, p. 9).

At the same time, it is widely recognised that some films are of a different kind. As part of an historical movement, these films have been associated with modernism or more vaguely with the "modern" film (Metz, 1974b; Kovács, 2007), but in a more systematic fashion they are often termed art films (Bordwell, 1985; Grodal, 2009). The reference point for discussions of the art film is typically European films, but this category also includes film making practices in other non-Hollywood national cinemas, especially in Asia and South America. Further, some American independent films may also be placed within the art film category. However, the practice within film studies of categorising films using this dichotomy at hand is problematic insofar as it reflects national exhibition habits within the United States (the division between mainstream versus art house cinema), but fails to address what European cinema looks like in Europe. First, there are a great number of national variants of genre films in European and other national cinemas, especially comedy. Second, there is a long tradition of non-comic films containing contemporary issues, based on historical events and adapta- 
tions of "canonical" literature. Most often these films are neither plain genre films nor art films. These films are "serious" in scope like the art film, but they are more accessible and easier to follow. They can have engaging narratives that do not follow specific genre forms. They may involve a love story, melodramatic events and moments of suspense. But genretypical subjects, narrative forms and emotional characteristics do not define these films in their overall form. I will suggest that this kind of film is best understood as a tradition of realism.

\section{Ways to understand realism}

The concept of realism is notoriously opaque, and it has been addressed in many different ways. Since the early days of film theory, the film medium has often been characterised in terms of its inherent or media specific realism (Münsterberg, 1970[1916]; Bazin, 1971; Metz, 1974a). The moving images simply appeared as a very convincing rendering of reality. On this perceptual level, watching the moving images is in many aspects like watching real events (Anderson, 1996). Influential theories in the 1970s and 1980s considered realism to be a certain form of enunciation with ideological implications (McCabe, 1986). In the tradition of critical theory inspired by Marx, Freud and variants of post-structuralist French theory, realism was considered as duping audiences into mistaking made-up fictions and artificially ordered and ideological formed worlds as the world (Baudry, 1974/75). Further, this broad idea of realism included all kinds of genres and aesthetic movements: "Whether we look to Hollywood, where realism is purchased at almost any price, or to the Italian neorealist cinema, we find that the struggle is to represent reality as effectively as possible" (MacCabe, 1986, pp. 179-180).

Despite its prominent position as a theoretical concept in film studies, realism first had its day as a groundbreaking aesthetic movement in paintings, novels and in the theatre about fifty years before the advent of cinema. Maybe it is for this reason that cinematic theories on realism have placed such an emphasis on techniques that could enhance what was considered to be specific to the film medium such as rendering the physicality of the world (Kracauer, 1961) or long takes making the flow of time directly perceptible by unfolding the phenomenological nature of the film medium (Bazin, 1971). But the idea of realism is not only considered in relation to medium specific properties (the moving images) and to certain techniques (long takes), but also in terms of content, for example in the form of an emphasis on social issues, a preference for dealing with working class people etc. In Kristin Thompson's words: "at intervals over the past few centuries, a notion has surfaced that the life of lower-class figures presented with the appearance of objectivity is more realistic than that of middle- or upper-class subjects" (Thompson, 1988, pp. 205-206).

Thus, there seem to be many ways to approach and define realism. Part of this confusion has historical reasons. But it also has to do with the fact that the term has been used across different media and representational forms (e.g., painting, film, literature) and been 
addressed in different academic traditions. Within film studies and related aesthetic areas, I believe realism can be conceived of on at least three different levels.

First, realism can be understood as related to audiovisual media, that is, the medium specificity of sound and moving images (media realism). The idea of medium specificity is prevalent in early writings on film theory in which the moving images are considered for their likeness to reality. This includes anecdotes regarding audiences that mistake moving images for reality (see also Gunning, 1990). More recent theories of perception and cognition emphasise similarities between how we perceive visual representations and natural phenomena in the everyday world. In this understanding, the film medium adapts itself to the hardwired built-in mechanisms of human perception. The effect is an experience of perceptual realism, or what Joseph Anderson terms "the reality of illusion" (Anderson, 1996). Another term for this effect is the "impression of reality", which also applies to unreal content: "Fantastic art is fantastic only as it convinces (otherwise it is merely ridiculous), and the power of unreality in film derives from the fact that the unreal seems to have been realized, unfolding before our eyes" (Metz, 1974a, p. 5). Most contemporary developments in computer-generated imaging are used to make super-natural or unrealistic actions appear as if real, that is, they combine perceptual realism with actions and events which are unreal or improbable on a cognitive level (Prince, 1996). Genre-realism in fantasy, science fiction and adventure films is very much about making otherwise incredible actions appear as if real.

Second, realism can be seen as "reality effects", that is, single stylistic features such as long shots in Italian neorealism (Bazin, 1971). This idea of realism as stylistic features that enhance our sense of witnessing something real cuts across aesthetic areas. In literature it can be the amount of detail in descriptive passages that gives the sense of a world that is present and attracts attention because it is simply there (Genette, 1981, p. 165). In a documentary film it can be the imperfections of sound and visuals that authenticate the film as a caught-in-the-moment-document of a world in constant transition (e.g., cinema veritéstyle), a style sometimes used to authenticate fiction films, as well as, e.g., in the opening sequence of Saving Private Ryan (1998).

Third, I will suggest that realism can be considered a film practice that implies more than single features or effects. By the term film practice, I intend to characterise specific kinds of films in their entirety rather than, say, any movie (media realism) or stylistic aspects of some movies (realistic effects). It is this idea of realism as a film practice that I discuss in the following. I will not deny that computer-generated images are central to discussions of how genre movies also rely on certain notions of realism, or that non-fiction can be discussed in terms of how reality-effects are based on specific stylistic features. But in the following, I will narrow my use of the concept of "realism" to three criteria: I will consider realism as fiction (as opposed to non-fiction), as serious (as opposed to comedy) and as something that characterises the overall or "global" form of a film (as opposed to single or local effects). 


\section{Three kinds of film practices: genre films, art films and realism}

What characterises Hollywood cinema and other classical narrative forms is that they all obey certain rules of genre:

For the phrase "genre films", referring to a general category, we can frequently, though not always, substitute "film narrative". Perhaps that is the real genre (Williams, 1984, p. 121).

In Hollywood, any film applies to some standard schemata concerning narrative form and subject matter, sometimes also stylistic norms (musicals, film noir). What Bordwell, Staiger and Thompson (1985) have termed "Classical Hollywood narration" is basically a narrative and stylistic master-scheme that covers all kinds of genre films. Thus, the combination of the institutional and economic practices of the Hollywood system and some basic rules about storytelling (tacitly agreed upon by producers and audiences) is what they term "a mode of film practice":

A mode of film practice is not reducible to an oeuvre (the films of Frank Capra), a genre (the Western), or an economic category (RKO films). It is an altogether different category, cutting across careers, genres, and studios [...] A mode of film practice, then, consists of a set of widely held stylistic norms sustained by and sustaining an integral mode of film production. Those norms constitute a determinate set of assumptions about how a movie should behave, about what stories it properly tells and how it should tell them, about the range and functions of film technique, and about the activities of the spectator. These formal and stylistic norms will be created, shaped, and supported within a mode of film production (Bordwell, Staiger \& Thompson, 1985, pp. xiii-xiv).

A mode of film practice includes the institutional framework that produces films. It guides individuals who make films. It is apparent in the features in the films themselves, and, finally, it includes norms that create expectations and guide audiences in experiencing films. A mode of film practice constitutes a system above individual genres.

David Bordwell has also considered other modes of film practices, such as the art film, but from an aesthetic rather than an institutional perspective. According to Bordwell, the European art film of the sixties constitutes a mode of film practice with its own narrative norms. These norms include combinations of objective and subjective narration with authorial comments in ways that maximise ambiguity (Bordwell, 1999[1979]; Bordwell, 1985). Despite differences among the self-conscious auteurs of the European cinema, their films are nevertheless similar insofar as they command certain viewer activities that are different from classical Hollywood narration. Whereas Hollywood cinema focuses on plot and combinations of cues and gaps in knowledge as strategies for engaging the audience in story construction (What will happen and what has happened?), art films focus on existential issues and are less concerned with plot than with interpretation and implied meaning (What does this film tell us about being a human being?). Furthermore, these films depend 
on institutional organisations other than Hollywood and they also, partly, depend on other audiences. First, common to European films, including art films, is that they are heavily supported and mostly financed by money from national states or cross-national organisations (e.g., at present, Euroimages and Nordic Film and TV fund) and are often co-produced with national public service media institutions. Second, art films may engage other audiences and for other reasons than classical genre-narratives. They primarily appeal to a well-educated audience who likes films with themes and stories that may be considered more "deep" or complex than simple action (see also Grodal, 2009, pp. 205-228). Thus, classical Hollywood narratives and art cinema are typically regarded as opposites in terms of their institutional frameworks, aesthetic norms and kinds of audiences, hence divided into popular, commercial and accessible genre films and high-brow, state-supported and difficult autonomous films (see also Elsaesser, 2005). But it is also a conceptual dichotomy between the formuladriven genre film and the more individualised art film which is typical within film studies. The question is whether or not this dichotomy is sufficient to describe main tendencies within European cinemas.

I think there are at least two serious problems with this dichotomy. First, the major proportion of European films are popular genre films, often national variations of comedy or crime fictions or sometimes re-workings of Hollywood genres (e.g., Luc Besson's Léon, 1994). Thus, the opposition between genre films and art films not only exists across the Atlantic but also within European national cinemas. Second, it is quite clear that non-genre European films can be art films. This is true for films by Austrian Michael Haneke (e.g., The Seventh Continent (Der Siebente Kontinent), 1989, and The White Ribbon (Das Weisse Band), 2009) and the Swede Roy Anderson (e.g., Songs from the Second Floor (Sånger från andra våningen), 2000), just as the Dane Lars von Trier makes art films that use familiar genres in unfamiliar ways (Antichrist, 2009). However, there are also many films which neither fully follow genre expectations nor can be described as art films. Some of the films by Swedish director Lukas Moodysson may be labelled youth films, but especially Lilja 4-ever (2002) is far from specific genre formulas and also Show Me Love (Fucking Åmål, 1998) is a different kind of story about love and identity - despite its happy ending. Another Swedish film, A Song for Martin (En sång för Martin, 2001), by Danish director Bille August combines psychological intimacy with a clear cut story that neither resembles melodrama nor art film. Even though a film such as the French Hide Away (Le Refugé, 2009) by Francois Ozon opens with a scene where a character realises that her boyfriend has died from an overdose and that she is pregnant (with his child), the rest of the film departs from both romantic and melodramatic narrative schemes.

The Dogma 95 movement, with its Manifesto and rules, appeared as a filmic and provocative experiment in the tradition of modernism and the art film (see also Hjort \& Mackenzie, 2003). Yet, the ten Danish Dogma 95 films that premiered between 1998 and 2004 can be seen as representative of three filmic prototypes. First, there are genre films like the romantic comedy Mifune (Mifunes sidste sang, 1999), second art films like The Idiots (Idiot- 
erne, 1998) and The King is Alive (2000) and, third, films which neither follow genre schemes nor have the indeterminacy of art film. These are films such as Kira's Reason: A Love Story (En kærlighedshistorie, 20001) and, partly, Open Hearts (Elsker dig for evigt, 2002) (see also Jerslev, 2004, on Open Hearts as realism). Thus, the Dogma 95 films mirror three different traditions in European cinema: genre films, art films and a third kind of film that I will characterise as realism (see also Langkjær, 2005, 2007).

Arguing for a conceptual triad of genre film, art film and realism may lead to confusion. One can possibly insist that realism (or a sub-category of realism) is like a genre in the sense that it follows rules by using certain themes, typical narrative patterns, and stylistic features etc. Further, the art film is obviously not completely autonomous (in opposition to formula-driven), because films belonging to this category do share certain characteristics, such as existential themes and a self-conscious play with narrative forms. They may not be considered less rule-bound than Hollywood-genres - they just follow different rules. In short, there is no such thing as single films which are not also films of a particular kind. A film will relate to certain prototype patterns (Rosch, 1973) or can be grouped together with other films by family resemblances (Wittgenstein, 1953; see also, Fowler, 1982; Lakoff, 1987). This implies that each film does not share all those characteristics that can be attributed to the category they belong to, but, nevertheless, each film has many of the central characteristics of the group. If one equates prototype patterns or family resemblance with the concept of genre, then any kind of film can be defined a genre film. The problem, however, is that film studies at large do refer to specific kinds of well-known narrative patterns, themes and styles when talking about genre films (Schatz, 1981; Neale, 2000) and those mentioned are typically exemplified by reference to the Hollywood cinema (e.g., Altman, 2000). Hence, I will use the conceptual triad of genre film, art film and realism to emphasise realism as a consistent film practice in opposition to an approach that considers realism as a question of partial features within specific genres or as strategies within some art films. This film practice has no obvious place as a sub-category of either Hollywood cinema or European art cinema. Rather, it is an umbrella-category in between genre films and art films that covers different sub-categories.

In what follows, I will characterise realism in terms of its textual features, such as its narrative form and prototypical themes. I will not deal with institutions, organisations or aspects of cultural politics that obviously support the making of this kind of film. Rather, I will narrow my focus to aesthetic or textual features. For this reason I will not talk about realism as a mode of film practice (a concept which includes those organisations that support such a film production), but only of realism as a film practice or an aesthetic norm.

\section{Realism as a film practice}

In his book on scriptwriting, Robert McKee (1999) presents an outline of three narrative prototypes that to a great extent resemble, respectively, classical narration, art film and the 
kind of realism I have in mind. Archplot is characterised by a single and active protagonist, causality and linear time within a continuous narrative with a closed ending. This prototype is very similar to classical narration and Kee's own example is Francis Ford Coppola's The Godfather (1972). Antiplot is characterised by coincidence, nonlinear time and inconsistent realities. This is quite similar to modernist variants of the art film, and Kee himself mentions Ingmar Bergman's Persona (1966) as an example. Finally, Miniplot covers plots with multiple and passive protagonists, internal conflicts and open endings; here McKee uses Bille August's Pelle the Conqueror (Pelle Erobreren, 1987) as a prime example (see McKee, 1999, pp. 44-58). There is no doubt that the Miniplot narrative in Pelle the Conqueror can count as social realism. Having said that, I suspect that Kee's description of the Miniplot could also fit other forms of realism: a narrative characterised by a passive protagonist dealing with inner conflicts and an open ending would also be a fitting description for Kira's Reason: A Love Story and many other films which can be characterised as psychological realism. In general, Miniplot is a more accessible narrative form than the Antiplot, because the term Miniplot covers a consistent type of fiction in which a series of actions follow each other, whereas the Antiplot defies simple causality. On the other hand, the Miniplot has less clear cut causality than is the case with the Archplot.

Even though Robert McKee is mainly concerned with dramaturgical aspects of the films, I believe his three narrative prototypes fit into these larger patterns of aesthetic film practice I have proposed in this article, that is, a tradition of realism which is considered a third film practice in between the genre film and the art film.

In a schematic form, some key features of narration, theme and style in relation to genre films, art films and realism can be characterised like the following:

Three kinds of film practices

\begin{tabular}{|c|c|c|c|}
\hline & Classic narration & Realism & Art film \\
\hline \multirow[t]{2}{*}{ Characters: } & Psychologically clear cut & $\begin{array}{l}\text { Psychologically defined but } \\
\text { complex }\end{array}$ & Complex and ambiguous \\
\hline & $\begin{array}{l}\text { Goal-oriented through } \\
\text { action }\end{array}$ & $\begin{array}{l}\text { Adapting to a situation through } \\
\text { attitude and conception of self } \\
\text { and others }\end{array}$ & Searching for meaning \\
\hline Conflicts: & Specific and outer-world & $\begin{array}{l}\text { Structural: intimate and social } \\
\text { relations }\end{array}$ & Existential \\
\hline \multirow[t]{2}{*}{ Plot: } & Causality & Episodic but accessible & Episodic and ambiguous \\
\hline & Closure & Open ending: A new beginning & $\begin{array}{l}\text { Open ending (also in } \\
\text { terms of interpretation) }\end{array}$ \\
\hline Style: & Emphasise plot & Emphasise plot & Stylized \\
\hline Fiction: & Consistent & Consistent & Inconsistency \\
\hline
\end{tabular}

Let me use Pelle the Conqueror as an example. The film consists of many subplots within the larger narrative, subplots which are not necessarily strongly connected. One subplot is about Pelle's father who wishes to marry what he believes is a widow. Another subplot 
centres upon the strong and courageous labourer Erik's rebellion. A third subplot follows a pregnancy and its fatal consequences. A fourth subplot shows the marital fight between Mr. and Mrs. Kongsgaard, which leads to one of the many tragic endings in the film. What connects these subplots is the fact that Pelle experiences most of these events as an involved eyewitness. Sometimes he is part of the events but most often he is an on-looker. This alignment with Pelle makes most actions "focalized" through him. It enhances the cruelty of most of the happenings because they are not only cruel in and of themselves, but cruelty experienced by a child. Thus, the central character perceives events more than he acts on them. His most conclusive act is when he leaves the farm in favour of an unknown future, an action which provides the film with its open ending.

This kind of realist film is to some extent similar to genre films, as it displays well-defined characters, a style that emphasises plot elements and a consistent fiction that makes the films more accessible than the art film. But realism also defines art films by its more episodic narratives, its open endings, and its reliance upon complex characters. The structural conflicts in realism cannot be solved by simple action. But the characters are nevertheless situated in a social or psychological context that makes it easier to relate to them than with the typical art film. In art films, the specificity of the social world or the "naturalism" of ordinary psychology often becomes vague in order to leave space for seeing characters and situations as representations of some basic and existential human concern, often stylised into symbolic form (Grodal, 2009, pp. 205-228). Thus, realism shares characteristics with both genre films and art films, but, nevertheless, it creates its own mixture of elements in films that can be accessible and engaging but yet also serious and "deep". The narratives involve recognisable fictional worlds, whether the films are intimate, psychological, social or historical in nature. They do not follow classical rules of genre, nor do they have the challenging, self-reflexive and ambiguous character of art films. Realist films are traditionally considered to have "cultural value" (like the art film), but they can also be popular in terms of tickets sold (like popular genre films).

In order to get a better idea of this very broad category of films, I will outline two subcategories that I believe are generally accepted in terms of realism, even though they are not always clearly defined. These are social realism and psychological realism.

\section{Social realism: the structural antagonist}

In film studies, realism is most often equated with social realism. Early realism in literature also emphasised social issues, and Raymond Williams has almost equated realism with social realism by characterising realism as "socially extended" just like he stresses its (leftist) political agenda (Williams, 1974). In film theory, the most typical examples of social realism are Italian neorealism (Thompson, 1988) and British "kitchen sink" realism (Lay, 2005). Social realism can be defined by its emphasis on social aspects of the fictional world depicted and how it influences characters: 
Social realism is a discursive term used by film critics and reviewers to describe films that aim to show the effects of environmental factors on the development of character through depictions that emphasise the relationship between location and identity (Hallam \& Marshment, 2000, p. 184).

This is a different kind of film than "classical narration". Any genre narrative involves one or more protagonists, something they want, and some obstacles they will have to deal with, and this kind of protagonist provides the plot with its forward drive and closure. In a detective film, the detective wants to figure out who, how and why in relation to a crime. When these goals are obtained, the narrative has come to an end. In a romance, a boy wants a girl (and vice versa), and the successful realisation of their romantic longing is what provides the narrative with its closure.

In social realism, the protagonist may want a bicycle in order to get the much needed job, or he may want the innocent girl he met in a bar. But films like Bicycle Thieves (Ladri di Biciclette, 1948) or Saturday Night and Sunday Morning (1960) are more about pride, self-esteem and identity than about specific goals and actions. Social emotions like shame, pride and humiliation (as opposed to basic emotions like fear in thrillers or happiness in romantic comedies) play a central role in the way characters behave and react in certain situations. Dramatic situations are most often structured by social conditions which define and set limits to how the protagonist can deal with life, not only in terms of work, education and material aspects, but also in terms of how he or she can make sense within his or her situation, typically through love, friendship and other intimate relations. The social world in social realism is not only society at large, but also the micro-social world of close relationships. In this sense, social realism is not so much about "the effects of environmental factors" (Hallam \& Marshment, 2000, p. 184) in a one-way determined fashion, but rather about specific ways to deal with a social environment. Even though it is beyond doubt that Bruno's father turns into a bicycle thief because he is driven by socially conditioned destitution, the engaging parts of Bicycle Thieves are related to how he reacts to this disturbing turn of events and struggles to not let go of his dignity. Thus, social realism is less about causality than about coping, less about obtaining a goal through actions than about adapting to a situation without losing one's integrity. We may pity people who do not manage to cope, such as the girl Grace who is raped and hangs herself in the New Zealand movie Once Were Warriors (1994). Or we may feel the pathos arising from depictions of oppression and rebellion in a historical epic like Pelle the Conqueror. In these films, the protagonists struggle and do their best despite the fact that there is a limited range of options available. In social realism, the social conditions structure the dramatic conflict; in other words, the real antagonist is structural. Yet, the films are usually not narratives about people trapped in pre-determined patterns. They are more about ways individuals deal with those structures. However, there is also a kind of naturalist variant of social realism in which the outcome seems to be a simple consequence of the initial situation and the social set-up. This can be observed in films such as La Haine (1995), Lilja 4-ever or the Danish film $R$ (2010). These films are about 
people who fail to adapt and become simple victims of social circumstances. However, this strong social causality is not characteristic of social realism as such, and should be considered a sub-category of social realism.

Social realism is similar to social melodramas in several aspects. However, one pivotal difference is that even though melodrama is socially situated, it is more about eternal values, about good and bad, than about the specific conditions characteristic of social realism. The melodrama and its orchestration of characters tend to be Manichaean (Brooks, 1976), whereas social realism's characters tend to be more complex; they are not only good people, but they have flaws as well (for example, the fathers in both Bicycle Thieves and Pelle the Conqueror). The characters in Bicycle Thieves, Saturday Night and Sunday Morning, Pelle the Conqueror and Once Were Warriors are all historically and socially situated. The narratives are episodic, they display complex characters and are more about people who struggle with self-identity and try to cope with work, friends, lovers and family than about moral imperatives.

\section{Psychological realism: the inner antagonist}

Whereas there is a certain agreement on how to define social realism, psychological realism may seem to lack a proper definition; for good reasons. First, there is an element of psychological realism to any film narrative in the sense that audiences understand characters' actions and reactions as meaningful, as long as they are psychologically motivated. Further, we understand fictional characters because we relate their actions to our knowledge of action and reaction patterns in the ordinary world. If somebody gives you a gift, you may feel happy. If somebody or something threatens you, fear or anger may be the result. In a similar fashion, a romantic comedy may involve a joyous scene where somebody receives a gift, or a science fiction film may involve an invasion from outer space that causes fear on the planet earth. Neither a romantic comedy nor a science fiction film is realism as such, but both kinds of films follow well-known genre formulas. Yet, in order to grasp the narrative, audiences do make sense of people, situations and human actions in ways that rely on what is considered plausible in terms of ordinary psychology. This even applies when actions and context is extra-ordinary or even fantastic. The Russian formalists have named the reliance upon ordinary knowledge "realistic motivation" (e.g., Shlovsky, 1965) even though it may be the psychological structure (danger elicits fear) more than the actual situation (extraterrestrial invasion) that connects with our knowledge of psychological patterns. From this point of view, almost any narrative would involve some elements of psychological realism.

Some theories examine the subject of psychological realism by connecting psychology with subjectivity. As a matter of fact, film theory since the 1970s has been much more occupied with subjectivity as a formal aspect of narration than with psychology as a subject matter, even film theories using cognitive psychology as an explanatory framework (e.g., Branigan, 1994). This may have to do with a long tradition within film studies for a 
theoretical bias towards questions of medium-specificity, in the sense that many film theories focus on the specific ways the film medium constructs psychological states through point-of-view shots, characters that hallucinate etc. Whereas psychology is about mental mechanisms vital to the understanding of any kind of human drama, questions of subjectivity involve camera angles, point-of-view shots, sound, music and many others stylistic choices. The issue of subjectivity (e.g., character subjectivity or unreliable narration) calls for an analysis of style and aesthetics (film as fine art), whereas the psychology of characters is more likely to be dealt with when analysing dramaturgical aspects of films. And for some reason, dramaturgical matters have mostly been left to writers of how-to books on scriptwriting (e.g., Field, 1979; Seger, 1994).

Most how-to books on scriptwriting emphasise how any narrative involves an overall story arc connected to the goals and actions of the protagonist. Syd Field claims that "the essence of character is action" (Field, 1979, p. 30). Creating a character through his or her goals and actions involves a story arc, which is structured by regular "turning points" or "plot points" (Field, 1979, pp. 114-131). A new situation necessitates new actions. Apart from visible actions in the physical world, narratives also involve an inner development. The main character has to learn a lesson, to become more mature and to conceive of him- or herself in a new perspective. This second and inner development is central to psychological realism. In A Song for Martin, the Alzheimer's disease and the gradual change of the male character's personality have severe implications that he and - as the narrative progresses his wife have to deal with. Hide Away it about the male character's attraction to a pregnant female but the attraction never leads to action. And the flash-back structure in Five Times Two $(2 \times 5,2004)$, Francois Ozon's story about the disintegration of a marriage, underlines the sense that the ending of the marriage is happening more than they are making it end. Many films by Danish director Nils Malmros are about the intimate world of young people struggling with love, parents and each other, like in Tree of Knowledge (Kundskabens træ, 1981) and The Beauty and the Beast (Skønheden og udyret, 1983). Overall, psychological realism is more about coming to terms with oneself than about actions in the outer world, and the narrative structure mirrors this inner development, which is more comprehensible than the fleeting existential conflicts in art films, but without the outer story arc and the melodramatic moralism central to the Hollywood version of serious, psychological dramas.

Whereas social realism takes place on a social scene that includes sociological and micro-sociological levels, psychological realism focuses on micro-sociological relations and intimate psychological development, and love, friendship and liberation from parents are central themes. This prototype of realism originates from the existential turn in the 1960s New Wave and, for example, Francois Truffaut's The Soft Skin (La Peau Douce, 1964) has many features in common with psychological realism. In psychological realism, the psychology of characters is not as vaguely defined and identities are less under existential scrutiny as in the majority of New Wave cinemas in Europe in the 1960s. In psychological realism, character psychology neither makes audiences understand their actions nor creates ambi- 
guity about their actions and intentions. Rather, in psychological realism, character psychology is the main issue and what the film is all about. A film such as the Danish Dogma 95 film Kira's Reason: A Love Story is basically a story about recovering from the loss of a child. Apart from plot elements such as marital fights, gatherings with family and friends and infidelity, the inner story arc follows the female protagonist Kira as she struggles to accept her loss and regain her belief in her marriage. In terms of outer action, the narrative is episodic but the depiction of a crisis and the inner development of a character (Kira) is more specific and comprehensible than is typical of the art film. In general, psychological realism is more episodic on the level of action than the genre film, but more accessible and comprehensible than the art film in terms of its central issue: the inner character development.

\section{In conclusion}

In this article I have considered realism as a third film practice in between genre films and art films. My intention of using the term film practice has been to emphasise that this approach to realism refers to a level of description above specific genres, and, further, that it includes films which are not really dealt with in film genre studies. I have also characterised two prototypes (or sub-categories) within realism: social realism and psychological realism. These prototypes may be called genres in the sense that they include films that share certain characteristics. However, within film studies, the concept of genre is traditionally associated with the Hollywood system. Thus, for reasons of scholarly tradition I have chosen not to talk about genres within realism.

Ironically, the concept of realism may owe much of its scholarly success to it vague definition. In between its more modest use as an adjective (something is realistic) and Grand Theories about Western representational systems (realism as a hegemonic mode), I have suggested that the term is useful for characterising an important tradition of film making in European (and other national) cinemas. Understood this way, the term covers a tradition of serious (or non-comic) films about contemporary or historical issues of a psychological or social kind. They deal with their themes in narrative forms that do not apply to basic genre rules, but, nevertheless, they tell their stories in accessible and often engaging ways that differentiate them from art films.

This indicates that the simple dichotomy so typical within film studies between formula-driven genre films and "original" art films is insufficient. Simply examining European cinema as individual films made by great auteurs neither captures the long tradition of popular national forms of basic genres nor the mainstream tradition of social and psychological realism that in most cases attract much greater national audiences than is typical for the (modernist) art film. I have suggested that these prototypes of realism are better to be conceived of as part of a third mode of film practice within European cinemas that needs to be explored in a more systematic fashion. 


\section{References}

Altman, R. (2000). Film/Genre. London: BFI.

Anderson, J.D. (1996). The Reality of Illusion. An Ecological Approach to Cognitive Film. Carbondale: Southern Illinois University Press.

Bazin, A. (1971). What is cinema? Il. Berkeley: University of California Press.

Baudry, J-L. (1974/75). Ideological effects of the basic cinematographic apparatus. Film Quarterly 28, no. 2. Bordwell, D. (1985). Narration in the fiction film. Madison: University of Wisconsin Press.

Bordwell, D. (1999 [1979]). The Art Cinema as a Mode of Film Practice. In L. Braudy \& M. Cohen (Eds.), Film Theory and Criticism. Oxford: Oxford University Press.

Bordwell, D., Staiger, J. \& Thompson, K. (1985). The Classical Hollywood Cinema. Film Style \& Mode of Production to 1960. London: Routledge.

Branigan, E. (1994). Narrative Comprehension and Film. London: Routledge.

Brooks, P. (1976). The Melodramatic Imagination. Balzac, Henry James, Melodrama, and the Mode of Excess. New Haven: Yale University Press.

Elsaesser, T. (2005). European Cinema: Face to face with Hollywood. Amsterdam: Amsterdam University Press.

Field, S. (1979). Screenplay. The Foundations of Screenwriting. New York: Dell Publishing.

Fowler, A (1982). Concepts of Genre. In A. Fowler, Kinds of Literature. An Introduction to the Theory of Genres and Modes. Oxford: Clarendon Press.

Genette, G. (1981). Narrative Discourse. An Essay in Method. New York: Cornell University Press.

Grodal, T. (2009). Embodied Visions. Evolution, Emotion, Culture, and Film. Oxford: Oxford University Press. Gunning, T. (1990). The Cinema of Attractions: Early Film, Its Spectator and the Avantgarde. In T. Elsasser \& A. Barker (Eds.), Early Cinema: Space - frame - narrative. London: BFI.

Hallam, J. \& Marshment, M. (2000). Realism and popular cinema. Manchester: Manchester University Press. Hjort, M \& MacKenzie, S (Eds.)(2003). Purity and provocation. Dogma '95. London: BFI.

Jerslev, A. (2004). Elsker dig for evigt - lige nu. In O. Christensen (Ed.), Nøgne billeder. De danske dogmefilm. Holte: Medusa.

Kovács, A.B. (2007). Screening Modernism: European Art Cinema, 1950-1980. Chicago: University of Chicago Press.

Kracauer, S. (1961). Theory of Film. The Redemption of Physical Reality. Oxford: Oxford University Press. Lakoff, G. (1987). Women, Fire, and Dangerous Things. Chicago: University of Chicago Press.

Langkjær, B. (2005). What was Dogme 95? Film International, issue 19, 4(1),

Langkjær, B. (2007). The Celebration as Non-naturalistic Naturalism and Stylized Realism. In A. GrualMidgal (Ed.), Naturalism and Realism in Film Studies, Excavatio (vol XXII, nos. 1-2). Alberta: AIZEN.

Lay, S. (2002). British Social Realism. From Documentary to Brit Grit. London: Wallflower Press.

MacCabe, C. (1986). Theory and Film: Principles of Realism and Pleasure. In P. Rosen (Ed.), Narrative, Apparatus, Ideology. A Film Theory Reader. New York: Columbia University Press.

McKee, R. (1999): Story. Substance, structure, style, and the principles of screenwriting. London: Methuen.

Metz, C. (1974a). On the Impression of Reality in the Cinema. In C. Metz, Film Language: A Semiotics of the Cinema. Oxford: Oxford University Press.

Metz, C. (1974b). The Modern Cinema and Narrativity. In C. Metz, Film Language: A Semiotics of the Cinema. Oxford: Oxford University Press.

Münsterberg, H. (1970 [1916]). The Film. A Psychological Study. New York: Dover Books.

Neale, S. (2000). Genre and Hollywood. London: Routledge.

Prince, S. (1996): True Lies: Perceptual Realism, Digital Images, and Film Theory. Film Quarterly, Vol. 49, No.

3., pp. 27-37. 
Article: Realism as a third film practice

Rosch, E.H. (1973). Natural Categories. Cognitive Psychology, 4, 328-350. Film Quarterly, 49(3), 27-37.

Seger, L. (1994). Making a good script great, 2nd Edition. Hollywood: Samuel French.

Shklovsky, V. (1965). Art as Technique. In M. J. Reis (Ed.), Russian Formalist Criticism: Four Essays. Lincoln: University of Nebraska Press.

Thompson, K. (1988). Breaking the Glass Armor. Neoformalist Film Analysis. Princeton: Princeton University Press.

Williams, A. (1984). Is a Radical Genre Criticism Possible? Quarterly Review of Film Studies 9, (2), 121-125.

Williams, R. (1974). A Lecture on Realism. Screen 18(1), 61-78.

Wittgenstein, L (1953). Philosophical Investigations. Oxford: Blackwell.

\section{Birger Langkjer \\ Associate Professor, PhD}

Department of Media, Cognition and Communication

Film and Media Studies Section,

University of Copenhagen, Denmark

bilang@hum.ku.dk 